\title{
Assessing the Macronutrient Status of Some Selected Soils in Bayelsa State, South-South Nigeria
}

\author{
Kelvin H. Diri*, Joseph O. Tate \\ Department of Crop and Soil Science, Faculty of Agriculture, Niger Delta University, \\ PMB 071, Yenagoa, Bayelsa State.
}

* Corresponding Author email:

kelvgee8@gmail.com

Article Histary

Received: 29 February 2020

Revised: 01 May 2020

Accepted: 01 June 2020

Published: 13 June 2020

Student(s)

- Kelvin Harrison Diri

Academic Year: 2019-2020

Course Level: Bachelor

Course Name: B.Sc. (Soil Science)

Course year: Final Year

Mentor(s)

- Joseph Oyibrakemi Tate

\begin{abstract}
Fertility status of soils within the south-south region of Nigeria varies both inter and intra states. Therefore, the study investigated the macronutrient status of some selected soils in Bayelsa State. Two farm sites in Opume (OPF) and Amassoma (AMF) with records of long term cultivation were randomly selected and soil samples randomly collected from each locality for physicochemical analyses. Data collected were subjected to statistical analysis of means and a post hoc regression analysis to determine relationships between soils and analyzed parameters. Results revealed that soils were loam to sandy clay loam and acidic with low pH levels. Exchangeable bases $\left(\mathrm{Ca}^{2+}, \mathrm{Mg}^{2+}, \mathrm{K}^{+}\right)$were low in AMF soils compared to OPF soils except for $\mathrm{Na}^{+}$. Organic carbon and organic matter were moderately low in both soils, however, AMF had lower contents. Total $\mathrm{N}$ were found to be critically low $(0.03 \%)$ in both soils. OPF had higher available phosphorus (5.09 $\mathrm{mg} / \mathrm{kg}$ ) while AMF had higher available Sulphur $(6.55 \mathrm{mg} / \mathrm{kg})$. Base saturation was moderate in OPF (50.44\%), however, not significantly different $(\mathrm{p}<0.05)$ from AMF. Similarly, Effective Cation Exchange Capacity (ECEC) was low in soils of both localities. Regression analysis showed that $\mathrm{pH}$ had significant positive relationships with sand, $\operatorname{Org} \mathrm{C}, \operatorname{Org} \mathrm{M}$, available $\mathrm{P}, \mathrm{TN}, \%$ B.S and the basic cations $\left(\mathrm{r}=0.534^{*}, 0.841^{* * *}, 0.837^{* * *}, 0.855^{* * *}\right.$, $\left.0.736^{* * *}, 0.856^{* *}\right)$ with a negative relationship with Exchangeable acidity and $\mathrm{SO}_{4}{ }^{2-}\left(\mathrm{r}=-0.799^{* *}\right.$ and $\left.-0.844 * * *\right)$. Org $\mathrm{C}$, Org $\mathrm{M}$ and TN had significant negative relationships with silt at both localities $\left(\mathrm{r}=-0.592^{* *},-0.592^{* *}\right.$ and $\left.-0.491 *\right)$ respectively. These results indicate clearly that the nutrient status of soils in the study areas are mostly controlled by $\mathrm{pH}$ and the textural distribution. It also indicates that improved soil management practices can improve the macronutrient status for increased crop production.
\end{abstract}

Keywords: Nutrients, Fertility, Concentration, Crop utilization 


\section{Introduction}

Soil is the most valuable and vital natural resource to man which is not renewable over a short period of time. It is the unconsolidated mineral on the surface of the earth which has been subjected to and shows effects of genetic and environmental factors [6]. It is a medium through which plants derive their nutrients for their growth and development which in turn serves as a means of providing the needs of humans for food and clothing [25]. Soils must be able to supply considerable amounts of nutrient elements that are vital for crop production. These nutrients are said to be essential due to their level of requirement by plants for complete metabolic process. The primary nutrients which are Nitrogen $(\mathrm{N})$, Phosphorus $(\mathrm{P})$ and Potassium $(\mathrm{K})$ are required in relatively large quantities, while the secondary nutrients Calcium (Ca), Magnesium $(\mathrm{Mg})$ and Sulphur (S) are required in moderate amounts and are given secondary importance in their supply and management [17].The fertility of soil is the ability of such soil to supply, in available forms, adequate plant nutrients in considerable amounts required for growth and reproduction that is void of any form of toxicity [13]. Therefore, the fertility of soils is one of the most important factor which controls the yield of crops grown within such soil [8].

The exploitative nature of modern agriculture coupled with harsh climatic conditions, mostly within the tropics, results in the degradation of soils that have contributed towards the accelerated depletion and imbalances of these essential nutrients [14]. These deficiencies however, have become a major setback to stability, productivity and sustainability of soils. Sustainability of these soils for crop production will therefore require adequate soil management practices with the capacity to enhance nutrient availability for plant utilization.

In Bayelsa State, soils are utilized mostly for agricultural activities that includes the cultivation of arable crops mostly at subsistence level. Disadvantageously however, exposure to harsh climatic conditions with little or no provisions for climate-smart practices facilitates land degradation and reduced crop yield. Hence, the need for sufficient information about the nutrient status of the soil must be made readily available for utilization in agricultural production; especially, fertilizer application for nutrient deficiencies in soils of interest. Although there is relatively sufficient information on constant addition of organic matter into soils through turnover of dead and decaying plant and animal biomass [20]; this however, does not meet plant requirement for optimal use. Within temperate soils, such can be achieved but with a known setback of high acidity resulting from high accumulation of soil organic matter with resultant slow decomposition, mineralization and stabilization due to very low temperature and high moisture regimes $[15 ; 19 ; 20]$. Conversely, in humid tropical soils, various factors such as high temperatures, rapid weathering, fluctuating $\mathrm{O}_{2}$ availability, Fe oxidation and reduction and mineralogy have been shown to expedite rate of organic matter decomposition [23; 4; 9]. Also, is the fast decay of the non-labile fractions. This in turn gives room for rapid depletion and making nutrients unavailable for crop utilization.

Currently, there are research evidences showing various sustainable means of improving fertility status. One of which is through natural attenuation by constant addition of organic matter to soils through dead and decaying planting roots [20]. This study therefore aims at assessing and quantifying the nutrient status of selected soils in southern Nigeria to help in providing hands-on information to farmers for improved agronomic practices, appropriate fertilizer types and application mode for deficient nutrient elements to improve productivity.

\section{Materials and Methods}

The study area is located in Bayelsa State, south-south of Nigeria which covers the selected sites for the assessment. The study sites are Opume, in Ogbia Local Government Area, and Amassoma in Southern Ijaw local Government Area which lies between Latitudes $4^{\circ} 57^{\prime} 58^{\prime} \mathrm{N}$, Longitude $6^{\circ} 07^{\prime} 28^{\prime} \mathrm{E}$, and Latitude $4^{\circ} 38^{\prime} 38^{\prime} \mathrm{N}$, Longitude $6^{\circ} 21^{\prime} 41^{\prime} \mathrm{E}$ respectively. The mean annual rainfall ranges from $2000-4000 \mathrm{~mm}$ per annum that spreads over 8-10 months of the year between the months of April and November which coincides with the wet season having a mean rainfall of $2500 \mathrm{~mm}$ per annum coupled with a fairly constant 
temperature of $30^{\circ} \mathrm{C}$. The State is bounded by Delta State on the North, Rivers State on the East and the Atlantic Ocean on the western and southern parts. The vegetation of the state is mainly freshwater swamp forests. These vegetation types are associated with the distinct soil units in the area and they constitute part of the complex Niger Delta ecosystem.

Soil samples were collected from three cultivated farms in each of the study sites. Within each unit, ten (10) surface soil core samples $(0-15 \mathrm{~cm})$ were collected randomly and bulked using a soil auger, bagged and well labeled, giving a total of six (6) composite samples. The bulk composite soil samples were air-dried, and gently crushed to pass through a $2 \mathrm{~mm}$ sieve, bagged, re-labeled, stored and was later subjected to analysis for the physico-chemical properties of soil using standard methods.

Particle size was determined by Bouyoucos hydrometer method as described by Estefan [7], soil pH was determined in water suspension at soil-water ratio of $1: 2(w / v)$ and in $0.01 \mathrm{M} \mathrm{CaCl}_{2}$ salt solution at ratio of 1:2 $(w / v)$ with the aid of glass electrode $\mathrm{pH}$ meter. Organic carbon was determined by dichromate wet oxidation method of Walkley and Black. Organic matter was calculated by multiplying percentage organic carbon (van Bemmelen factor) by 1.724 [17]. Total Nitrogen was determined by macro kjeldahl method. Available phosphorus was determined by Bray P-1 method of Bray and Kurtz [3]. Exchangeable bases were extracted using $1 \mathrm{~N} \mathrm{NH}_{4} \mathrm{OAc}, \mathrm{Ca}^{++}$and $\mathrm{Mg}^{++}$were analyzed using PGI 990 Atomic Absorption Spectrophotometer (PG Instruments Ltd., UK), while $\mathrm{K}^{+}$and $\mathrm{Na}^{+}$were determined using ATS 200S Flame Photometer (ATS-Technology, Cyprus). The exchangeable acidity (EA) was determined by leaching the soil using $1 \mathrm{~N} \mathrm{KCl}$ and the extract titrated with $0.01 \mathrm{~N} \mathrm{NaOH}$. Cation exchange capacity was determined using the $1 \mathrm{~N} \mathrm{NH}_{4} \mathrm{OAc}$ method, effective cation exchange capacity (ECEC) was evaluated by summing up the exchangeable bases and the exchange acidity. The means and standard deviation were used, simple correlation of coefficients was also used to show the relationship between the soil chemical and physical properties.

\section{Results and Discussion}

\subsection{Particle size distribution}

Results from laboratory analysis showed that the texture of the soils varied from loam to silty clay loam in Amassoma and sandy loam to sandy clay loam in Opume. The silt fraction of the soil ranged from $30-$ $67.5 \%$ across both study sites. However, the silt fraction was highest at OPF $250 \pm 4.96 \%$. The sand fraction ranged from $10-40 \%$ with mean of $28.7 \pm 14.16 \%$ at Amassoma and $12.5-62.5$ with mean of $39.2 \pm 21.79 \%$ at Opume. Clay fraction of the soil was low at both study sites and ranged from $7.5-22.5 \%$ with mean of $25 \pm 16.35 \%$ at Opume and $15-33.5 \%$ with a mean of $21.2 \pm 9.43 \%$ at Amassoma. The variability in particle size fractions of soils in Amassoma was higher than that of Opume soils. The variance of the particle size fractions for sand, silt and clay were 633.3, 468.8, and 356.3 respectively. There was no distinct variation in moisture content between Opume soils and Amassoma soils as reported in Table 1.

Table 1: Physical properties of the studied soils

\begin{tabular}{|c|c|c|c|c|c|}
\hline \multirow{2}{*}{ Location } & Moist. C & Clay & Silt & Sand & $\begin{array}{c}\text { Textural } \\
\text { Class }\end{array}$ \\
\cline { 2 - 6 } & \multicolumn{2}{|c|}{$(\%)$} & 62.5 & SL \\
\hline OPF 1 & 37.4 & 7.5 & 30.1 & 12.5 & SCL \\
\hline OPF 2 & 67.6 & 45.0 & 67.5 & 42.5 & SCL \\
\hline OPF 3 & 39.5 & 22.5 & 30.3 & $49.17 \pm 21.79$ & \\
\hline Mean \pm SD & $42.89 \pm 14.37$ & $25.00 \pm 16.35$ & $43.50 \pm 6.81$ & 40.1 & L \\
\hline AMF 1 & 40.7 & 15.1 & 45.2 & 10.1 & SCL \\
\hline AMF 2 & 51.2 & 33.8 & 56.2 & 36.2 & L \\
\hline AMF 3 & 35.4 & 15.2 & 48.8 & $28.73 \pm 14.16$ & \\
\hline Mean \pm SD & $42.37 \pm 6.87$ & $21.27 \pm 9.43$ & $50.00 \pm 4.96$ & & \\
\hline
\end{tabular}

$\mathrm{OPF}=$ Opume Farm; AMF = Amassoma Farm; L = Loamy; SCL = Sandy Clay Loam; SL = Sandy Loam 
Although OPF2 recorded highest moisture value of $67.6 \%$ as against $51.2 \%$ in AMF2, It shows that these soils are mostly flooded and may pose a threat to crop production. This is an indication that both localities have similar moisture regimes within soils and will therefore require similar managerial practices for improved crop performance.

\subsection{Soil reaction and Exchange acidity}

Soil reaction in distilled water and $\mathrm{CaCl}_{2}$ indicated that the soils ranged from strongly acidic to moderately acidic (Table 2). Soil pH $\left(\mathrm{H}_{2} \mathrm{O}\right)$ at Opume ranged from 3.00-6.10 with mean of 5.60 \pm 0.49 while that of Amassoma ranged from $5.10-5.50$ with a mean value of $5.17 \pm 0.26$. The $\mathrm{pH}$ values of the soils in $\mathrm{CaCl}_{2}$ was found to be lower than that of $\mathrm{pH}\left(\mathrm{H}_{2} \mathrm{O}\right)$. Soil $\mathrm{pH}$ in $\mathrm{CaCl}_{2}$ ranged from 4.40-5.20 with mean of $4.73 \pm 0.37$ at Opume and $4.08-4.50$ with a mean of $4.23 \pm 0.23$. The overall results clearly indicate that the soils are acidic. The low pH levels of the soils can be attributed to leaching of soluble bases as a result of long-term average annual rainfall ranging from 2000 - $4000 \mathrm{~mm}$ per annum coupled with continuous farming without fertilization, a similar trend was observed by Attoe [2] for soils in Etung local government Exchangeable acidity $\left(\mathrm{H}^{+}, \mathrm{Al}^{3+}\right)$ was found to be $<2 \mathrm{cmol}_{\mathrm{c}} / \mathrm{kg}$ but varied from low to medium at both locations (Opume and Amassoma) when compared to critical values given by [1]. Mean values of exchangeable acidity at Opume $\left(1.70 \pm 0.52 \mathrm{cmol}_{\mathrm{c}} / \mathrm{kg}\right)$ and Amassoma $\left(1.90 \pm 0.34 \mathrm{cmol}_{\mathrm{c}} / \mathrm{kg}\right)$ represents increased acidity which in turn causes adverse effect on plants. The adverse effect of both acid cations may include Manganese and Boron toxicity, decreased microbial activities and nutrient deficiency which in turn affects plant root development. However, soil $\mathrm{pH}$ can influence availability of most essential nutrient elements required by crops as CEC and base saturation are also $\mathrm{pH}$ dependent.

\subsection{Organic carbon, Total Nitrogen, Available Phosphorus and Sulphur}

Organic carbon content of soils from both study sites varied between low to high with the highest value recorded at OPF1 $(1.86 \%)$. Organic carbon ranged from $0.85-1.86 \%$ and $0.92-1.55 \%$ with a mean value of $1.25 \pm 0.46 \%$ and $1.14 \pm 0.31 \%$ for both locations (Opume and Amassoma). These values translate to organic matter content of $1.45-3.21 \%$ and $1.60-2.68 \%$ with mean values of $2.16 \pm 0.80 \%$ and $1.97 \pm 0.53 \%$ for both locations respectively. The mean values indicate that the soils had moderate to high organic carbon and organic matter content suitable for arable crop production. This result corroborates Roy et al [22] who also reported low organic matter in soils under cassava cultivation in Iwo and Oshogbo zones in south western Nigeria. The soils in the study area is marked with high rainfall and an iso-hyperthermic temperature regime [5] which favors the high rate of organic matter decomposition.

It was observed that both study sites had similar total nitrogen content ranging from $0.02-0.04 \%$ with mean of $0.03 \pm 0.01 \%$ (Table 2). Based on these values, total $\mathrm{N}$ was low, deficient and below critical level. The low total nitrogen values could be attributed to high C:N ratio (42:1) which affects the rate of organic matter decomposition. Since microorganisms require nitrogen for rapid multiplication and accelerated activity, they tend to utilize available native nitrogen which translates to lower amounts of total nitrogen in the soil. Soil organic matter content can however be used as an index of $\mathrm{N}$ availability because the $\mathrm{N}$ content in soil organic matter is relatively constant. Therefore, low organic matter content with a reciprocating high mineralization rate within the soils coupled with leaching due to high amount of precipitation could also be attributes to soil nitrogen content. Intense crop cultivation, low plant residue incorporation and low $\mathrm{pH}$ level of the soils are factors responsible for the low total $\mathrm{N}$ content of the soil. These finding are in agreement with result reported by Ramana et al [18] who observed low N content in cultivated soils in Sri Ganganagar India. 


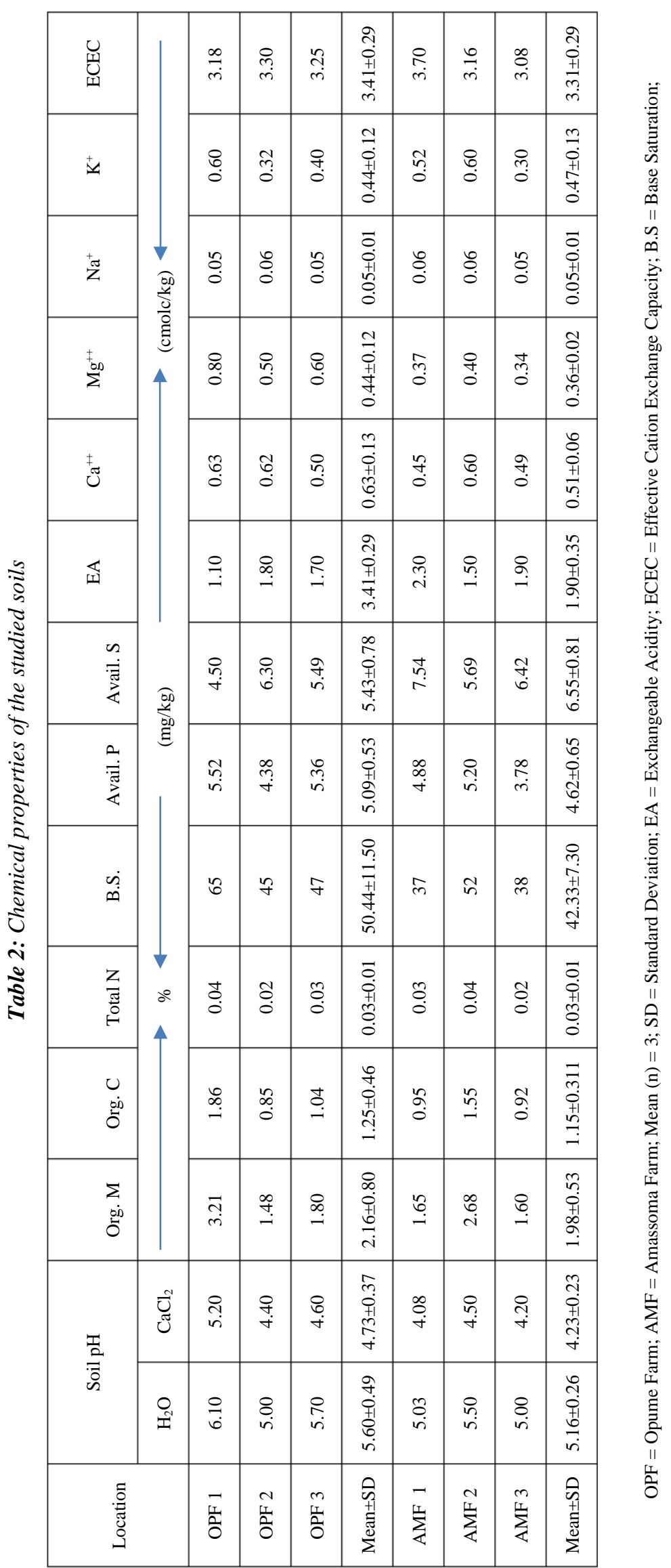


Diri et al., Adv. J. Grad. Res.; Vol. 8, Issue 1, pp: 105-114, July 2020

Available phosphorus was generally low and below critical level of $<20 \mathrm{mg} / \mathrm{kg}$ [11] at both study areas with a mean value of $5.08 \pm 0.5 \%$ and $4.62 \pm 0.64 \%$ which could be as a result of excessive leaching. According to ratings by [11] it was noted that the acidic nature of the soils as a result of low $\mathrm{pH}$, ECEC, and organic matter content of the soils contributed greatly to low P-availability. These soils will however, require application of phosphorus fertilizer to enhance phosphorus level in the soil. Available sulphur ranged from $4.50-6.30 \mathrm{mg} / \mathrm{kg}$ and $5.69-7.54 \mathrm{mg} / \mathrm{kg}$ with a mean value of $6.5 \pm 0.81 \mathrm{mg} / \mathrm{kg}$ and $5.43 \pm 0.78 \mathrm{mg} / \mathrm{kg}$ at Amassoma and Opume respectively. These soils were sulphur deficient $(<10 \mathrm{mg} / \mathrm{kg})$ according to [10]. Sulphur reduction in the study area could be due to the lack of Sulphur addition to the soil and continous removal by crops. Titirmare et al [24] observed similar trend in sulphur reduction in soils by crop uptake.

\subsection{Exchangeable Bases}

The soils exchangeable calcium content of the soils was low $\left(<2 \mathrm{cmol}_{c} / \mathrm{kg}\right)$ [12] and had values that ranged from $0.50-0.63 \mathrm{cmol}_{c} / \mathrm{kg}$ and $0.45-0.60 \mathrm{cmol}_{c} / \mathrm{kg}$ with mean values of $0.58 \pm 0.06 \mathrm{cmol}_{\mathrm{c}} / \mathrm{kg}$ and $0.51 \pm 0.07$ $\mathrm{cmol}_{\mathrm{c}} / \mathrm{kg}, \mathrm{Mg}^{++}$concentration in soil was moderate with mean values of $0.63 \pm 0.13 \mathrm{cmol}_{\mathrm{c}} / \mathrm{kg}$ and $0.37 \pm 0.02$ $\mathrm{cmol}_{c} / \mathrm{kg}$. Exchangeable $\mathrm{Na}^{+}$content was low $\left(<0.10 \mathrm{cmol}_{\mathrm{c}} / \mathrm{kg}\right)$. The low $\mathrm{Na}^{+}$values are clear indications that the soils have good soil aggregation coupled with good pores distribution. Exchangeable potassium values indicated that $\mathrm{K}^{+}$concentration varied from medium to high and was above critical range $(<0.2$ $\left.\mathrm{cmol}_{\mathrm{c}} / \mathrm{kg}\right)$ with the highest value of $\mathrm{K}^{+}$concentrations at OPF1 $\left(0.60 \mathrm{cmol}_{\mathrm{c}} / \mathrm{kg}\right)$ and AMF2 $\left(0.60 \mathrm{cmol}_{\mathrm{c}} / \mathrm{kg}\right)$. The potassium content of these soils can be attributed to the presence of easily weatherable rich in $\mathrm{K}$ mineral. This was in line with findings by [5] for Oruma soils in Bayelsa state. Pulakehi et al [16] also observed similar results from soils in North Karnataka stating that the high $\mathrm{K}$ content in the soils indicates the presence of micaceous parent material. The soils had mean $\mathrm{K}^{+}$values of $0.47 \pm 0.13 \mathrm{cmol}_{\mathrm{c}} / \mathrm{kg}$ and $0.44 \pm 0.12 \mathrm{cmol}_{c} / \mathrm{kg}$. The basic cations decreased in the order $\mathrm{K}^{+}>\mathrm{Mg}^{++}>\mathrm{Na}^{+}>\mathrm{Ca}^{++}$at Opume and Amassoma respectively. The ECEC of the soils were generally low, base saturation ranged from $45-65 \%$ and $37-38 \%$ with mean values of $50.44 \%$ and $42.33 \%$. This could be as a result of the low exchangeable bases.

\section{Coefficient of Correlation}

A Spearman rho correlation ( $\mathrm{r}$ ) for both soils is shown in Table 3. Soil $\mathrm{pH}\left(\mathrm{H}_{2} \mathrm{O}\right)$ and $\left(\mathrm{CaCl}_{2}\right)$ were both found to correlate positively and significantly with Organic C $\left(0.841^{* * *}\right)$, Organic M $\left(0.837^{* * *}\right)$, available P $\left(0.855^{* * *}\right)$, Total N $\left(0.736^{* * *}\right), \mathrm{Mg}^{++}\left(0.782^{* * *}\right), \mathrm{Ca}^{++}\left(0.734^{* *}\right)$, \%B.S $\left(0.856^{* * *}\right)$ and $\mathrm{K}\left(0.594^{* *}\right)$. However, it was negatively and significantly correlated with EA $(-0.799 * *)$ and $\mathrm{SO}_{4}{ }^{2-}\left(-0.844^{* * *}\right)$ at $\mathrm{p}<0.05$, 0.01 , and 0.001 respectively. The result is an indicator that the $\mathrm{pH}$ of both soils of the study sites strongly influenced fertility status considering its relationship to the physico-chemical properties of the soils. It could be inferred that among all soil properties, $\mathrm{pH}$ is most influential and should be given priority attention if improvement is required, especially for soils within the Niger Delta belt. Furthermore, such relationship can be attributed to the high rainfall level within the region which can last from April to November annually at estimated 2,500 mm per annum. Organic C correlated positively and significantly with Total N, Organic $\mathrm{M}$, available $\mathrm{P}, \mathrm{K}$, and $\%$ B.S. with ( $\mathrm{r}$ ) values of $0.916^{* * *}, 0.999^{* * *}, 0.764^{* * *}, 0.861^{* * *}, 0.787^{* * *}, 0.787^{* * *}$ respectively. This indicates that higher Organic $\mathrm{C}$ content can give rise to organic matter that is a storehouse for most plant required nutrients. Ramana et al [18] also reported similar relationship. Conversely, Organic Showed a negative and very weak correlation with silt $\left(-0.592^{* *}\right)$ which few studies have shown such relationships between $\mathrm{C}$ and soil texture. Organic $\mathrm{M}$ is a storehouse for essential mineral elements, which is released during process of mineralization. Therefore, the positive and strong correlation between Organic matter, available $\mathrm{P}\left(0.853^{* * *}\right)$, Total $\mathrm{N}\left(0.915^{* * *}\right), \mathrm{K}\left(0.865^{* * *}\right)$ and $\%$ B.S. $\left(0.785^{* * *}\right)$ was anticipated following results obtained from Organic C. This further shows that soils of Amassoma and Opume have moderate amounts of plant essential nutrients. However, adopted management practices could determine, to a large extent, its availability for crop utilization. 


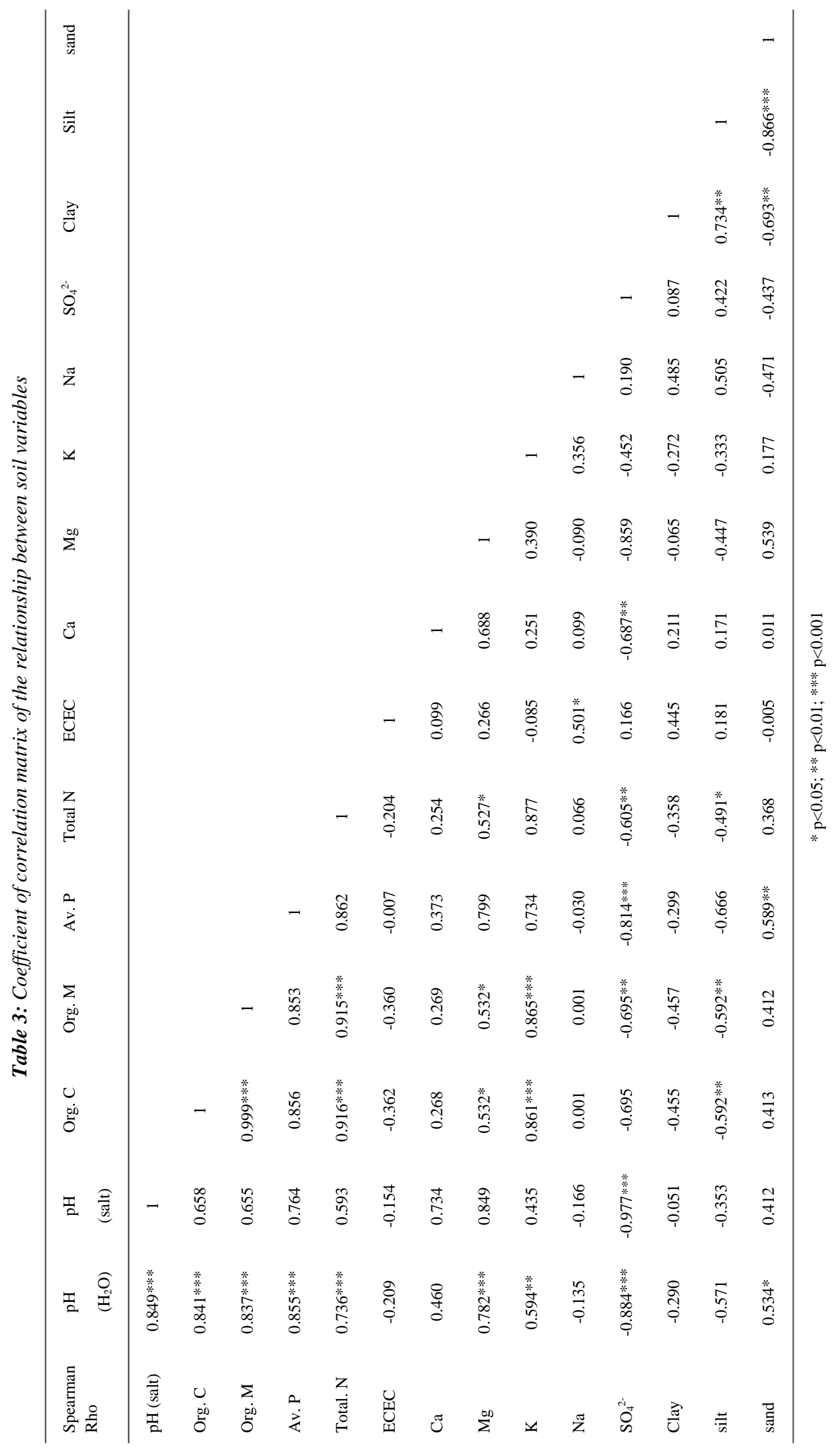


As these soils are predominantly high in organic matter, fertilizer requirement is rather low and advantageous for environmental friendliness. Conversely, it was a negative and weak correlation observed with EA, Aluminum saturation, $\% \mathrm{Al}, \mathrm{SO}_{4}{ }^{2-}$ and Silt at $(\mathrm{r})$ values $-0.847 * * *,-0.588^{* *},-0.702^{* *},-0.695^{*}$, $0.592 *$ respectively. Although studies have shown relationships between Organic M and soil acidity, this further gives an insight to the type of relationship as Aluminum based acidity is mostly due to the oxidation of the Alumino complex. This further relates to the significant and positive correlation between Moisture content and $\% \mathrm{Al}$ saturation, which indicates hydrolysis of $\mathrm{Al}^{3+}$ leading to the release of $\mathrm{H}^{+}$ions hence, a decrease in soil $\mathrm{pH}$ as recorded in the soils in the study area. There was also, a positive and significant correlation between Total $\mathrm{N}$ and $\mathrm{Mg}^{++}, \mathrm{K}$ and \%B.S. However, this relationship was observed to be weak. Total N correlated positively and significantly with $\mathrm{Mg}\left(0.527^{* *}\right)$, Potassium $\left(0.877^{* * *}\right), \%$ B.S. $\left(0.727^{* * *}\right)$ but negatively with EA, Aluminum saturation, $\mathrm{SO}_{4}{ }^{2-}$ and silt with $(\mathrm{r})$ values of $-0.750^{* * *},-0.482^{*},-0.605^{*}$, $-0.491 *$ respectively. Exchangeable acidity comprises of exchangeable $\mathrm{H}^{+}$and $\mathrm{Al}^{3+}$. Exchangeable acidity correlated with ECEC $\left(0.612^{* *}\right)$, Aluminum saturation $\left(0.747^{* * *}\right), \% \mathrm{Al}\left(0.768^{* * *}\right), \mathrm{SO}_{4}^{2-}\left(0.803^{* * *}\right)$ but negatively with \%B.S. $\left(-0.863^{* * *}\right)$ as shown in Table 3 . The positive correlations depict that an increase in a soil property will result in an increase in the other soil property, while a negative correlation implies that an increase in one soil property will lead to a decrease in the other.

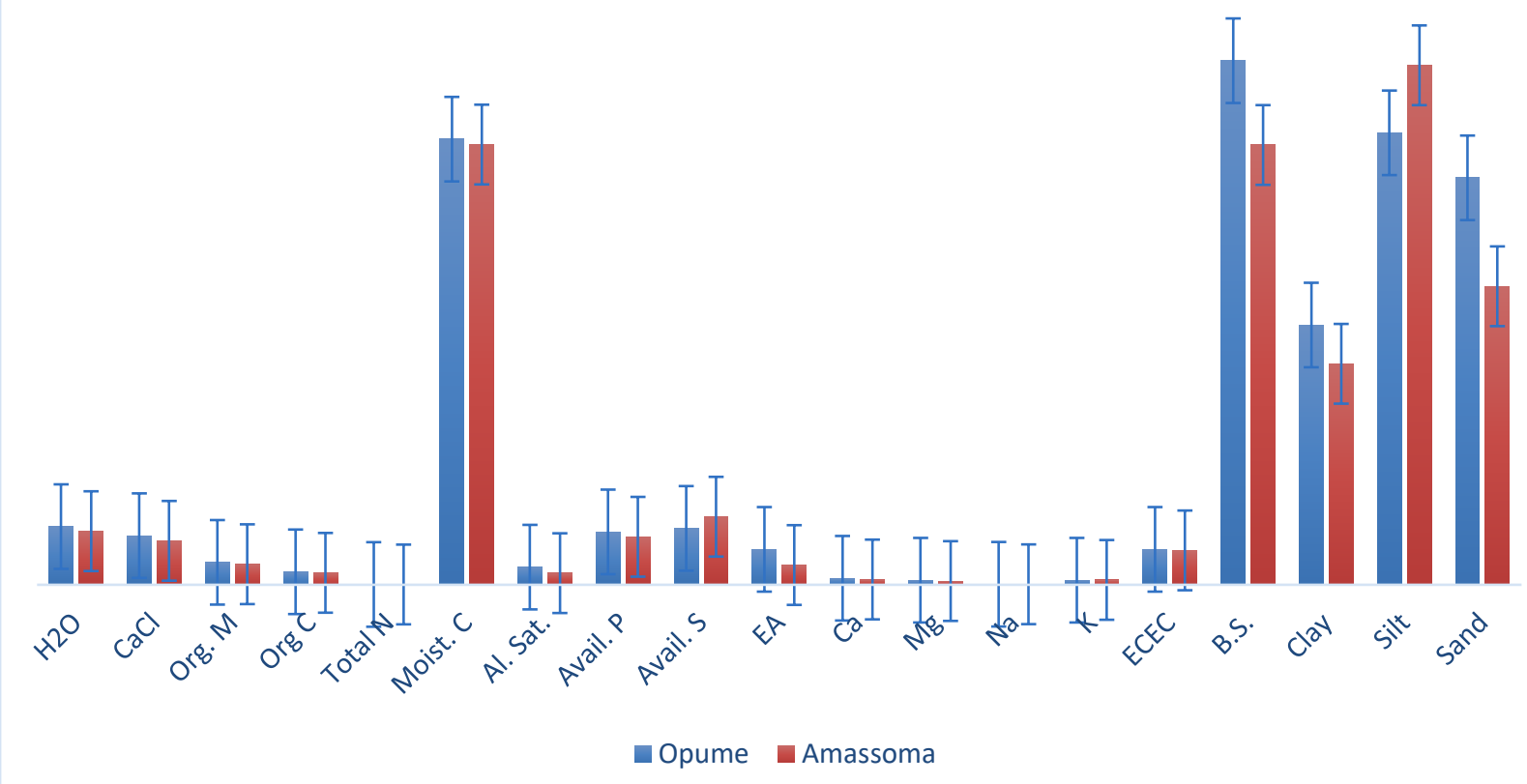

Fig. 1: Comparative analysis of physico-chemical properties of Opume and Amassoma soils

A comparison between Opume and Amassoma soils as shown in Figure 1 indicates that within all parameters analyzed, only \%B.S. and Sand content were significantly different $(\mathrm{p}<0.05)$. All other parameters were not significantly different from each other as it translates to both soils having similar fertility levels.

\section{Conclusions}

Optimum production of a cropping system depends on an adequate supply of plant nutrients. The soil macronutrients are responsible for the growth and development of any crop and a deficiency in any of these nutrients in the soil will reflect its deficiency on the crop. On the basis of field and analytical findings, it can be concluded that the soils in the study areas are characterized by low soil $\mathrm{pH}$ levels, low organic matter content which might be due to rapid mineralization of organic matter and low ECEC accompanied with high amount of rainfall and low to medium base saturation, which affects the availability of these 
macronutrients. Therefore, in order to boost soil productivity and enhance agricultural transformation in the study area, it is recommended that the soils be limed so as to increase the $\mathrm{pH}$ of the soil, which will result in increased microbial activity and subsequently undergo fertilization with organic and mineral fertilizers so as to curtail the effects of soil acidity as a result of the use of acidifying inorganic fertilizers. Agronomic practices such as fallowing, shifting cultivation can also be employed so as to curtail nutrient losses from the soil due to plant uptake, as well as adopting new innovations on climate-smart agricultural practices.

\section{Declarations}

\subsection{Acknowledgement}

The authors are grateful to Prof. Adeniyi Olu. Obi, Mr. Joseph O. Tate and the team of technologists in the Crop and Soil Science Laboratory for their advice and assistance during this research and in preparing this manuscript.

\subsection{Competing Interests}

The authors declared that no conflict of interest exist in the publication of this work

\section{How to Cite this Article:}

K. Diri and T. Joseph, "Assessing the Macronutrient Status of Some Selected Soils in Bayelsa State, South-South Nigeria", Adv. J. Grad. Res., vol. 8, no. 1, pp. 105-114, Jun. 2020. https://doi.org/10.21467/ajgr.8.1.105-114

\section{References}

[1] Adamu, G.K., Aliyu, A.K., and Jabbi, A.M. (2014), Fertility assessment of Soils under rice cultivation in Kadawa, Garun Mallam Local Government Kano State. Academic Research International, 5(1), 92.

[2] Attoe, E. E. (2018) Fertility Status of Soils of the two major cocoa producing Local Government Areas (Etung and Ikom) in Cross River State, Nigeria.

[3] Bray, R.H., Kurtz L.T. (1945). Determination of Total, Organic and Available Form of P in Soils. Soil Sci. 59: pp. 45-59.

[4] Cleveland, C. C., Reed, S. C., \& Townsend, A. R. (2006). Nutrient regulation of organic matter decomposition in a tropical rain forest. Ecology, 87(2), 492-503. https://doi.org/10.1890/05-0525

[5] Dickson, A.A., Allison-Oguru, E.A \& Isirimah, N.O. (2002). Fertility Capability Based Land Evaluation in Relation to socioeconomic Conditions of Small-Scale Farmers in Bayelsa state of Nigeria. Indian Journal of Agricultural Research 86, pp. 10-16.

[6] Eash Neal S., Thomas, J. Sauer., Deb O’Dell., and Evah Odoi. (2015). Soil science Simplified. John Wiley and Sons. P. 20-22.

[7] Estefan, G., Sommer, R. \& Ryan, J. (2013). Methods of Soil, Plant and Water Analysis: A manual for the West Asia and North Africa, International Center for Agricultural Research in the Dry Areas (ICARDA). p.30-33.

[8] Lone, P. A., Bhardwaj, A. K., Shah, K. W., \& Bahar, F. A. (2016). Assessment of soil macronutrient status of some threatened medicinal plants of Kashmir Himalaya, India. Research Journal of Botany, 11(1-3), 18-24.http://dx.doi.org/10.3923/rjb.2016.18.24

[9] Hall, S. J., \& Silver, W. L. (2013). Iron oxidation stimulates organic matter decomposition in humid tropical forest soils. Global change biology, 19(9), 2804-2813. https://doi.org/10.1111/gcb.12229

[10] Hariram and Divivedi, K.N., (1994). Delineation of Sulphur Deficient Soil Groups in theCentral Alluvial Tract of Uttar Pradash. J. Indian Soc. Soil Sci., 54: 508-512.

[11] Horneck, D.A., Sullivan, D.M., Owen, J.S., \& Hart, J.M. (2011). Soil test interpretation guide.

[12] Jahn, R., Blume, H. P., Asio, V. B., Spaargaren, O., \& Schad, P. (2006). Guidelines for soil description. FAO.

[13] Osman, K. T. (2012). Soils: principles, properties and management. Springer Science \& Business Media.

[14] Oladipo, M. O. A., Njingab, R. L., Achid, S. S., Ogunleyea, P. O., Alfab, B., \& Ibrahim, A. A. (2012). Analysis of savannah and rainforest soils of Nigeria using thermal neutron activation analysis technique. International Journal of Science andTechnology, 2(8), 583-589.

[15] Poeplau, C., Don, A., Six, J., Kaiser, M., Benbi, D., Chenu, C., \& Gregorich, E. (2018). Isolating organic carbon fractions with varying turnoever rates in temperate agricultural soils A comprehensive method comparison. Soil Biology and Biochemistry, 125, 1026.https://doi.org/10.1016/j.soilbio.2018.06.025

[16] Pulakeshi, H. B. P., Patil, P. L., Dasog, G. S., Radder, B. M., Bidari, B. I., \& Mansur, C. P. (2012). Mapping of nutrients status by geographic information system (GIS) inMantagani village under northern transition zone of Karnataka. Karnataka Journal of Agricultural Sciences, 25(3)

[17] Pribyl, D. W. (2010) "A Critical Review of the Conventional SOC to SOM Conversion Factor," Geoderma, Vol. 156, No. 3-4, pp. 75-83.https://doi.org/10.1016/j.geoderma.2010.02.003

[18] Ramana, Y. V., Jat, L. K., Meena, S. K., Singh, L., Jatav, H. S., \& Paul, A. (2015). Available Macro Nutrient Status and their Relationship with Soil Physico-Chemical Properties of Sri Ganganagar District of Rajasthan, India. Journal of Pure and Applied Microbiology, 9(4), 2887-2894.

[19] Rasmussen, C.; Blankinship, J. C.; Heckman, K.; Wieder, W. R.; Keiluweit, M.; Lawrence, C.R.; Berhe, A. A.; Crow, S. E.; Druhan, J. L.; Hicks Pries, C. E.; Marin-Spiotta, E.; Plante, A.F.; Schadel, C.; Schimel, J. P.; Sierra, C. A.; Thompson, A. \& Wagai, R. (2018). 
Diri et al., Adv. J. Grad. Res.; Vol. 8, Issue 1, pp: 105-114, July 2020

Beyond clay: towards an improved set of variablesfor predicting soil organic matter content.Biogeochemistry (2018) 137:297-306. https://doi.org/10.1007/s10533-018-0424-3

[20] Reddy, S. A., Goroji, P. T., \& Ravalan, B. M. (2014). Assessment of soil NPK status under Ceiba pentandra plantation in Theni district of Tamil Nadu. Soil and Environment, 33(1), 72-78.

[21] Roy, R.N.; Fink, A.;Blair, G.J.; Tandon, H.L.S. (2006). "Chapter 3: plant nutrients and basics of plant nutrition". Plant nutrition for food security: a guide for integrated nutrient management. Rome: Food and Agriculture Organization of the united nations.pp.25-42.

[22] Salami, B. T., \& Sangoyomi, T. E. (2013). Soil fertility status of cassava fields in South Western Nigeria. Journal of Experimental Agriculture International, 152-164. https://doi.org/10.9734/AJEA/2013/2088

[23] Six, J., Feller, C., Denef, K., Ogle, S., de Moraes Sa, J. C., \& Albrecht, A. (2002). Soil organic matter, biota and aggregation in temperate and tropical soils-Effects of no-tillage. https://doi.org/10.1015/agro:2002043

[24] Titirmare, N. S., Takankhar, V. G., Indulkar, B. S., Lilhare, M. A., \& Thosar, G. D. (2019). Macronutrients status of red soils from Hasegaonwadi of Latur district. IJCS, 7(5),1099-1103.

[25] Wagh, G.S., Chavhan D.M., and Sayyed, M.R.G. Physiochemical Analysis of Soils from Eastern part of Pune City. Universal Journal of Environmental Research and Technology 3(1) 2013.

Publish your books with AIJR publisher-

* Publish with ISBN and DOI.

* Publish Thesis/Dissertation as Monograph.

* Publish Book Monograph.

* Publish Edited Volume/ Book.

* Publish Conference Proceedings

* Retain full copyright of your books.

Submit your manuscript at books.aijr.org
Publish your research article in AIJR journals-

* Online Submission and Tracking

* Peer-Reviewed

* Rapid decision

* Immediate Publication after acceptance

* Articles freely available online

* Retain full copyright of your article. Submit your article at journals.aijr.in 